Received: November 20, 2017

Revision received: March 22, 2018

\title{
Research on Innovation Method of College English Translation Teaching Under the Concept of Constructivism
}

\author{
Hao Liang ${ }^{1}$ \\ Hebei University
}

\author{
Xiaopeng $\mathrm{Li}^{2}$ \\ Hebei University
}

\begin{abstract}
At present, most colleges and universities in China still adopts the traditional teaching method for college English translation teaching, that's, teachers giving lectures while students listening to in the classroom, and the traditional translation teaching method has its advantages, but there is no active interaction and cooperation between teachers and students. Based on the new standard of college English teaching reform and the theory of constructivism, this paper puts forward a new teaching mode and method of college English translation, aiming at improving the effect and quality of translation teaching and focusing on guiding students to develop their own active learning ability and cognitive ability, so as to help them grasp new knowledge more quickly and effectively, appreciate the unique charm of English and Chinese and the similarities between the two ways of expression.
\end{abstract}

\section{Keywords}

Constructivism • College English Translation • Teaching Innovation • Translation Teaching • English and Chinese Bilingualism

${ }^{1}$ Correspondence to: Hao Liang (MA), School of Foreign Languages, Hebei University of Science and Technology, Shijiazhuang 050000, China. Email: lh5693@163.com

${ }^{2}$ School of Foreign Languages, Hebei University of Science and Technology, Shijiazhuang 050000, China. Email: 1xp1022@163.com

Citation: Liang, H., \& Li, X. P. (2018). Research on Innovation Method of College English Translation Teaching Under the Concept of Constructivism. Educational Sciences: Theory \& Practice, 18(5), 2455-2461. http://dx.doi.org/10.12738/estp.2018.5.145 
For the majority of college English translation courses, teachers still use traditional teaching modes to develop students' translation abilities (Wang, Guangyu, Mei \& Wei,, 2011), teaching vocabulary, grammar, idioms and figures of speech in a traditional way (Lillywhite, Lee, Tippetts \& Archibald, 2013); introducing translation criteria; comparing different sentence structures; providing examples of translation methods and techniques; or randomly selecting some fragments of the articles written by some famous writers for translation teaching practice, and then telling the students the reference answer (Du, Li \& Fei, 2010). Of course, this traditional teaching method is very important and effective (Anco \& Bluman, 2012). However, the traditional teaching mode is a passive learning process for students, lack of active teacher-student interaction and cooperation, and basic translation principles and rules, experience and skills cannot be effectively passed on to students (Zhang \& Zhang, 2011), nor can students fully accept them, all of which are shortcomings of traditional translation teaching.

The traditional college English translation teaching model described above is behaviourism ( $\mathrm{Li}$, Wang, Zhang \& Zhou, 2010), and behaviourists believe that the purpose of education is to transfer knowledge to learners, while the task of the learners is to achieve the goal set by the educators (Tsai, Lin, Lee, Chang \& Hsu, 2013). It ignores the psychological process of learners in the process of knowledge transfer. After years of practice, more and more people have realized this shortcoming. In the 1960s, cognitivism replaced behaviourism as the dominant theory (Uzunoglu \& Quriesh, 2012). More attention is focused on how to process and understand knowledge in the mind. The improvement of this theory resulted in constructivism. Constructivism initiated the modern teaching method of translation course, which makes educators think about how to produce a student-centered translation course (Yang et al., 2014). Thinking about how to change the teacher's function; thinking about how to activate the teaching of principles, theories, methods and skills in translation are issues of this paper to be discussed and practiced.

This paper first analyzes and studies the new standards of college English translation teaching reform and the problems existing in traditional teaching, and uses the theory of constructivism, and expounds the innovative teaching mode of improving college English translation teaching from the perspective of teachers and students. Then, this paper proposes four practical modes and teaching methods of college English translation teaching based on constructivism, and gives the concrete analysis and discussion, emphasizing the importance of cultivating students' initiative in the learning process and calling upon teachers to pay special attention to the development of students' ability of autonomous learning and continuous learning.

\section{College English Translation Teaching Guided by Constructivism}

Constructivism is a kind of philosophy theory, epistemology, or learning theory, and discusses how to construct the meaning of knowledge from the current knowledge structure. This theory on the nature of human learning guides the constructivist learning theory and teaching methods (Dori, Feldman \& Sturm, 2012). Constructivism refers to that the learners are not passively waiting for the enrichment of knowledge, but when new knowledge enters into the learners' existing knowledge system, it's necessary to form a connection with the learners' previous knowledge and experience, and actively construct his own knowledge. Constructivism is 
Liang, Li / Research on Innovation Method of College English Translation Teaching Under the Concept...

$\overline{\text { regarded as one of the most prosperous learning theories nowadays. It pays more attention to learners' subjective }}$ cognition than all theories in history. Therefore, constructivism pays more attention to constructing an environment in which learners explore knowledge actively rather than passively.

In all kinds of research fields, theory and practice are equally important. Therefore, constructivism, which originates from cognition, has important guiding significance to college English translation classroom teaching. The goal of teaching is to help learners transform external objective things, that's, knowledge and its structure, into internal cognitive structure. The purpose of learning is to build their own understanding, not just to remember the so-called "right" answer. Constructivism is very different from traditional behaviorism. Education is not only the output of teachers, but also the spontaneous learning process of individual students, not through listening but the experience of the environment. In other words, the construction of knowledge and its system is actively obtained by the students themselves. As popular in the field of foreign language learning, a language is controlled by students but not instilled by teachers. In the effective classroom teaching, teachers guide students to study actively. Teachers are both collaborators and organizers, and students are carriers of knowledge and subject of learning. Therefore, the learning process should be the interaction between teachers and students.

\section{Important guidance of constructivism to students' learning}

Learning motivation largely depends on the learner's learning potential. The sense of competence and belief in the potential to acquire knowledge are influenced by factors such as time, space and environment. Emotion is input into the process of learning and closely related to experience; positive feeling produces happiness and excitement, which is transformed into motivation to encourage students to study harder. A democratic and harmonious atmosphere and a power to comprehend knowledge is an essential prerequisite for sustained success and progress. At the same time, teacher's evaluation is very important to guide students to construct knowledge in mind.

The goal of constructivism is to cultivate lifelong learners to be good at self-control, self-regulation, selfanalysis and self-evaluation. The general assumption of counterproof is that all learning is discovered rather than taught, and that even if a teacher tells students something, the students still need to use the obtained information to do psychological manipulation and make new knowledge their own. In fact, this is an ability to make good use of learning strategies, that's, how to learn.

\section{Important guidance of constructivism to teachers' teaching}

As the organizer and instructor of the learning process, teachers should have a certain understanding of the learning methods and contents of the students. Teachers should play an active role in the learning process, turn their roles into facilitators, and help learners understand and construct their own knowledge. In the studentcentered model classroom, teachers are considered to be part of the learning environment in a broad sense, which contributes to the learner's active learning. This theory emphasizes personality. For a long time, people have paid too much attention to the development of group and general character, and neglected the individual 
diversity, which is accompanied by the traditional learning process in the way of filling duck or examination paper. What teachers should do is to design each class on the basis of each student's personality and provide students with a wide space to show their talents and develop their personality, thus achieving the ultimate goal and enhancing each student's ability.

\section{College English Translation Innovation Teaching Practice Based on Constructivism}

According to the theory of constructivism, the following teaching practice can be carried out in college English translation course.

\section{Improve the interaction of translation classes so that students can learn the skills of translation}

Constructivism holds that learning is a process of constructing meaningful representation and learner's experience learning. During learning, learners should be regarded as observers, participants, and even agents who actively transform and build knowledge in a way that suits them. College English translation course has practical characteristics. Learners need to construct their own knowledge through a great deal of practice. Before each translation class, teachers should design various tasks in advance and guide students to take an active part in the teaching process. Students acquire methods and skills through practice. The practice of this kind of teaching and learning is completely contrary to the traditional teaching methods and techniques taught mechanically, and the assignment of homework inside and outside the classroom to improve their translation ability.

In the teaching practice of college English translation course based on constructivism, teachers can consider the participation of students in the design of each teaching lesson. For example, let students choose some sentences or paragraphs from textbooks, such as basic English and advanced English to practice translation, even think about what the students have translated from a new perspective, and tell them new translation methods and techniques used. They can choose some classics and fine works from the extracurricular reading material to appreciate; or first do translation exercises and then start a new chapter of study, providing students with a more standard interpretation of translation, so that students can more clearly and systematically construct their own knowledge system, in order to quickly achieve the teaching goals. The following table shows various available forms of interactive college English translation teaching practice.

Table 1

Interactive Form of Translation Teaching

\begin{tabular}{lll}
\hline interactive stage & \multicolumn{1}{c}{ interactive level } & \multicolumn{1}{c}{ interactive form } \\
\hline \multirow{2}{*}{ before class } & student-student & group discussion \\
& student-computer & on-line consult \\
in class & student-student & group question and answer \\
& student-teacher & catechism \\
after class & student-student & translation evaluation \\
& student-teacher & translation reflection \\
\hline
\end{tabular}




\section{Pay attention to the learning process so that students can accumulate experience in the process of translation}

Constructivism emphasizes the subjective understanding and experience accumulation of learning, knowledge is the accumulation of individual experience, and the construction of new knowledge is based on the previous experience. Despite the temporary lack of adequate college English translation theory, students are able to translate materials into target languages based on their experience. Therefore, experience is as indispensable as the construction of translation knowledge. In the design of college English classroom teaching, we should pay attention to the combination of learning process and teaching goals, provide help for students and enrich their experience. In addition, we should help students develop a sense of learning strategies, and effective strategies are partly successful.

\section{Encourage students to study independently, so that students' translation ability is constantly improved in practice}

Modern education emphasizes "student-centered" and universities should provide an environment conducive to the growth and learning of each student. Cultivating students' knowledge acquisition ability, independent thinking ability and innovation ability is the ultimate goal of our college English teaching program. In order to achieve this goal, teachers should play the role of facilitators in the classroom, rather than teaching subjects in a didactic way, guiding students to understand independently. In the process of learning, teachers should translate the role of giving answers into providing guidance and creating an environment to help students reach their own conclusions. In the teaching of college English translation, we should constantly explore this problem. At the same time, for the teachers for translation course, teachers are also often inspired by the translation works of some excellent students. Although I sometimes get challenged and even rejected, I still encourage their creativity and enthusiasm. The key is not whether these answers are correct, but the students' autonomous learning consciousness and the students' thinking and practice, developing the learning ability with experience accumulated in practice.

\section{Positive evaluation of the effect makes students in the process of translation learn self-regulation and improvement}

According to the theory of constructivism, teachers' evaluation on each student's performance plays an important role in building up their positive learning feeling. Usually, students are eager to be praised by their teachers after they think they have done a good job in translation. Teachers are advised to try a variety of possible praise methods rather than formal praise methods such as "very good, good, right, and correct", which are too rigid and simple to inspire their enthusiasm for further practice and learning. Therefore, we should be fully aware of the power and charm of positive evaluation, do our best to make teaching methods attractive, teaching content encouraging, and teaching methods rich and colorful, so that the learning process becomes a kind of fun. Constructivist theory holds that it is very effective to combine the theory with the comment and 
Liang, Li / Research on Innovation Method of College English Translation Teaching Under the Concept...

analysis of students' work, and to combine the perceptual knowledge in the teaching material with the students' wisdom. In this way, knowledge is deeply and steadily rooted in their minds.

At the same time, the students also actively feedback the teaching mode of constructivist translation course, and the following table is the result of feedback questionnaire survey.

Table 2

The Questionnaire Investigation of the Innovative Teaching Mode

\begin{tabular}{lc}
\hline Item & Percent \% \\
\hline I love the translation class this semester & 89.6 \\
I am very fond of translation teaching mode & 87.2 \\
The translation class let me benefit a lot & 87.4 \\
Let me know more about the translation methods and techniques & 88.5 \\
Let me know the collaborative and diversity of translation & 89.4 \\
Let me more interested in the translation & 90.6 \\
I will continue to translation study & 91.2 \\
\hline
\end{tabular}

\section{Conclusion}

This paper deeply analyzes and studies the new standard of college English translation teaching reform, reexamines the existing problems in translation teaching from the perspective of constructivism, and puts forward the innovative teaching mode of college English translation teaching under the guidance of constructivism. This innovative teaching mode emphasizes the importance of cultivating students' initiative in the learning process, and calls on teachers to pay special attention to cultivating students' cognitive ability. In a word, constructivism adds new content to college English translation teaching practice, provides a new model for classroom teaching, and expounds a new learning concept to students who are accustomed to passively accepting knowledge. It brings new enlightenment and experience to the classroom teaching of college English translation.

\section{References}

Anco, S. C., \& Bluman, G. (2012). Direct construction method for conservation laws of partial differential equations. European Journal of Applied Mathematics, 13(5), 213-219. http://dx.doi.org/10.1017/S0956792501004661

Dori, D., Feldman, R., \& Sturm, A. (2012). From conceptual models to schemata: An object-process-based data warehouse construction method. Information Systems, 33(6), 567-593. http://dx.doi.org/10.1016/j.is.2012.02.002

Du, D., Li, K., \& Fei, M. (2010). A fast-multi-output RBF neural network construction method. Neurocomputing, 73(10), 2196-2202. http://dx.doi.org/10.1016/j.neucom.2010.01.014

Li, Dong., Wang, X., Zhang, X. L., \& Zhou, C. (2010). Study on the rule-based business model—Structure, function and the construction method. China Industrial Economics, 30(9), 101-111. http://dx.doi.org/10.1007/978-3-642-16750-8_9

Lillywhite, K., Lee, D. J., Tippetts, B., \& Archibald, J. (2013). A feature construction method for general object recognition. Pattern Recognition,46(12), 3300-3314. http://dx.doi.org/10.1016/j.patcog.2013.06.002 
Liang, Li / Research on Innovation Method of College English Translation Teaching Under the Concept...

$\overline{\text { Tsai, W. H., Lin, S. J., Lee, Y. F., Chang, Y. C., \& Hsu, J. L. (2013). Construction method selection for green }}$ building projects to improve environmental sustainability by using an MCDM approach. Journal of $\begin{array}{lllll}\text { Environmental Planning } \quad \& \quad \text { Management, } & \text { 56(10), }\end{array}$ http://dx.doi.org/10.1080/09640568.2012.731385

Uzunoglu, S. S., \& Quriesh, A. (2012). A method of adapting construction education in architectural design education. Procedia - Social and Behavioral Sciences, 51(10), 546-552. http://dx.doi.org/10.1016/j.sbspro.2012.08.204

Wang, B., Guangyu, H. E., Mei, S., Chen, Y., \& Wei, L. (2011). Construction method of smart grid's assessment index system. Automation of Electric Power Systems, 35(23), 1-5. http://dx.doi.org/10.1016/S10036326(11)60685-7

Yang, B. X., Huang, J., Liu, K., Ni, Y. H., Tong, X., \& Gen, W. B. (2014). Ontology construction and semantic modeling method research of education resources within the architecture of cloud service. Applied Mechanics \& Materials, 631-632(2), 1016-1022. http://dx.doi.org/10.4028/www.scientific.net/AMM.631632.1016

Zhang, J., \& Zhang, D. (2011). A novel ensemble construction method for multi-view data using random crossview correlation between within-class examples. Pattern Recognition, 44(6), 1162-1171. http://dx.doi.org/10.1016/j.patcog.2010.12.011 